\title{
Converting wasteland into wonderland by earthworms-a low-cost nature's technology for soil remediation: a case study of vermiremediation of PAHs contaminated soil
}

\author{
Rajiv K. Sinha • Gokul Bharambe • \\ David Ryan
}

(C) Springer Science+Business Media, LLC 2008

\begin{abstract}
Earthworms in general are tolerant to many chemical contaminants including heavy metals and organic pollutants in soil and can bio-accumulate them in their tissues. Earthworms species like Eisenia fetida, Eisenia tetraedra, Lumbricus terrestris, Lumbricus rubellus and Allobophora chlorotica have been found to remove heavy metals $(\mathrm{Cd}, \mathrm{Pb}, \mathrm{Cu}, \mathrm{Hg}$, etc.) pesticides and lipophilic organic micropollutants like the polycyclic aromatic hydrocarbons (PAH) from the soil. They 'absorb' the dissolved chemicals through the moist 'body wall' in the interstitial water and also 'ingest' by mouth while the soil passes through the gut. They either 'bio-transform' or 'biodegrade' the chemical contaminants rendering them harmless in their bodies. Meanwhile the quality of the soil is improved significantly in terms of physical, chemical and biological properties as the worms thoroughly upturn and disperse the soil, ingest large volumes of soil and excrete nutritive materials (NKP and micronutrients) in the form of 'vermicasts' along with millions of beneficial soil microbes including nitrogen fixers.
\end{abstract}

Keywords Vermiremediation technology using earthworms - Earthworms convert wasteland into wonderland $\cdot \mathrm{PAH}$ - carcinogenic, mutagenic and immunodepressive chemical - Earthworms-a soil detoxifying agent - Earthworms bio-accumulate, biodegrade and bio-transform chemicals

\section{Introduction}

Large tracts of arable land are being chemically contaminated due to mining activities, heavy use of agro-chemicals in farmlands, landfill disposal of toxic wastes and other developmental activities like oil and gas drilling. Rarely is farmland in the developing nations free of persistent pesticides (e.g. aldrin, chlordane, dieldrin, endrin, heptachlor, mirex, toxaphene, etc.). According to National Environment Protection Council there are over 80,000 contaminated sites in Australia-30,000 in New South Wales, another 30,000 in Queensland, 10,000 in Victoria, 4,000 in South Australia, 4,000 in Western Australia, 1,000 in Northern Territory and 500 each in Tasmania and the Australian Capital Territory (ACT). There are 40,000 contaminated sites in the United States; 55,000 in just six European countries and 7,800 in New Zealand. There are about 3 million contaminated sites in the Asia-Pacific. These also include the abandoned mine sites along with the closed landfills. The contaminated sites mostly contain heavy metals cadmium $(\mathrm{Cd})$, lead $(\mathrm{Pb})$, mercury $(\mathrm{Hg})$, zinc $(\mathrm{Zn})$, etc., and chlorinated compounds like the PCBs and DDT. Cleaning them up mechanically by excavating the huge mass of contaminated soils and disposing of them in secured landfills will require billions of dollars. There is also great risk of them leaching underground (aggravated by heavy rains) and contaminating the groundwater.

Earthworms referred to by Sir Charles Darwin as unheralded soldiers of mankind work day and night in soil, and have over 600 million years of experience in land and soil management. Vermiremediation is a low-cost, convenient technology for combating soil and land pollution. Earthworms in general are tolerant to many chemical contaminants in soil including heavy metals and organic pollutants and have been reported to bio-accumulate some 
of them in their tissues. Certain species of earthworms such as Eisenia fetida, Aporrectodea tuberculata, Lumbricus terrestris, Lumbricus rubellus, Dendrobaena rubida, Dendrobaena veneta, Eiseniella tetraedra and Allobophora chlorotica have been found to remove heavy metals, pesticides and lipophilic organic micropollutants like the polycyclic aromatic hydrocarbons (PAH) from the soil (Contreras-Ramos et al. 2006). E. fetida has been used as the test organisms for different soil contaminants and several reports indicate that $E$. fetida tolerates $1.5 \%$ crude oil (OECD 2000). Earthworms also inhibit soil-borne pathogens and work as a detoxifying agent for polluted soil. It reduces Salmonella population in soil to about $30 \%$ (Safawat et al. 2002).

\section{Earthworms improves soil quality}

Significantly, vermiremediation leads to improvement in the quality of soil and land where they inhabit. Earthworms swallow large amount of soil everyday, grind them in their gizzard and digest them in their intestine with aid of enzymes. Only $5-10 \%$ of the material ingested is absorbed into the body and the rest is excreted out in the form of fine mucus-coated granular aggregates called 'vermicastings', which are rich in NKP (nitrates, phosphates and potassium), micronutrients and beneficial soil microbes including the 'nitrogen fixers' and 'mycorrhizal fungus' (Chaoui et al. 2003). The organic matter in the soil undergo 'humification' in the worm intestine in which the large organic particles are converted into a complex amorphous colloid containing 'phenolic' materials. About one-fourth of the organic matter is converted into humus. The colloidal humus acts as 'slow release fertilizer' in the soil (Butt 1999).

During the vermiremediation process of soil, the population of earthworms increases significantly benefiting the soil in several ways. Earthworms promote soil fragmentation and aeration and brings about soil turning and dispersion. On an average, $12 \mathrm{t} / \mathrm{ha} /$ year of soil or organic matter is ingested by earthworms, leading to upturning of $18 \mathrm{t}$ of soil/year, and the world over at this rate it may mean a 2 in. humus layer over the globe (Bhawalkar and Bhawalkar 1994). Earthworms are in fact regarded as 'biological indicator' of good fertile soil. One acre of wasteland when transformed into fertile land may contain more than 50,000 worms of diverse species. Bhawalkar and Bhawalkar (1994) experimented and concluded that an earthworm population of 0.2-1.0 million per hectare of polluted land/wasteland can be established within a short period of 3 months.

Vermicastings of earthworms contain enzymes like amylase, lipase, cellulase and chitinase, which continue to break down organic matter in the soil to release the nutrients and make it available to the plant roots even after they have been excreted (Sinha et al. 2002; Chaoui et al. 2003). The nitrogenous waste excreted by the nephridia of the worms is mostly urea and ammonia. The ammonium in the soil is bio-transformed into nitrates. Bhawalkar and Bhawalkar (1994) found that earthworm recycle nitrogen in the soil rapidly. The quantity of nitrogen recycled is significant ranging from 20 to $200 \mathrm{~kg} \mathrm{~N} / \mathrm{ha} /$ year. The mycorrhizal fungi transfer phosphorus by increasing solubilisation of mineral phosphate by the enzyme phosphatase.

Earthworms host millions of beneficial microbes (including the nitrogen fixers) in their gut and excrete them in soil along with nutrients nitrogen $(\mathrm{N})$ and phosphorus $(\mathrm{P})$ in their excreta (Singleton et al. 2003).

Earthworms improve the physical, chemical and biological properties of the soil to enhance its fertility. The presence of earthworms also reduces 'soil salinity' and neutralizes $\mathrm{pH}$ of soil. Farmers at Phaltan in Satara district of Maharashtra, India, applied live earthworms to their sugarcane crop grown on saline soils irrigated by saline ground water. The yield was $125 \mathrm{t} / \mathrm{ha}$ of sugarcane and there was marked improvement in soil chemistry. Within a year there was $37 \%$ more nitrogen, $66 \%$ more phosphates and $10 \%$ more potash. The chloride content was less than 46\%. Farmer in Sangli district of Maharashtra, India, grew grapes on eroded wastelands and applied vermicasting at $5 \mathrm{t} / \mathrm{ha}$. The grape harvest was normal with improvement in quality, taste and shelf life. Soil analysis showed that within 1 year $\mathrm{pH}$ came down from 8.3 to 6.9 and the value of potash increased from 62.5 to $800 \mathrm{~kg} / \mathrm{ha}$. There was also marked improvement in the nutritional quality of the grape fruits (Bhawalkar and Bhawalkar 1994).

\section{Biology of earthworms}

Earthworms are long, narrow, cylindrical, bilaterally symmetrical, segmented soft-bodied invertebrates. The body is dark brown, glistening and covered with delicate cuticle. They weigh over 1400-1500 mg after 8-10 weeks. On an average, 2000 worms weigh $1 \mathrm{~kg}$ and 1 million worms weigh approximately $1 \mathrm{t}$ (Visvanathan et al. 2005). Usually the life span of an earthworm is about 3-7 years depending upon the type of species and the ecological situation (Edward and Lofty 1972). The gut of the earthworm is inhabited by millions of microbial decomposers. They have 'chemoreceptors' which aid in search of food. Earthworm body contains $65 \%$ protein (70-80\% high quality 'lysine-rich protein' on a dry weight basis), $14 \%$ fats, 14\% carbohydrates and 3\% ash (Gerard 1960).

Earthworms multiply very rapidly. They are bisexual animals and cross-fertilization occurs as a rule. After copulation the clitellum (a prominent band) of each worm eject lemon-shaped 'cocoon' where sperms enter to fertilize the 
eggs. Up to 3 cocoons per worm per week are produced. From each cocoon about 10-12 tiny worms emerge. Studies indicate that they double their number at least every 60 days. Given the optimal conditions of moisture, temperature and feeding materials earthworms can multiply by $2^{8}$, i.e. 256 worms every 6 months from a single individual. Each of the 256 worms multiplies in the same proportion to produce a huge biomass of worms in a short time. The total life cycle of the worms is about 220 days. They produce $300-400$ young ones within this life period. A mature adult can attain reproductive capability within 8-12 weeks of hatching from the cocoon. Red worms takes only 4-6 weeks to become sexually mature. Earthworms continue to grow throughout their life and the number of segments continuously proliferates from a growing zone just in front of the anus (Hand 1988; Visvanathan et al. 2005).

\section{Ecology of earthworms}

Earthworms are burrowing animals and form tunnels by literally eating their way through the soil. The distribution of earthworms in soil depends on factors like soil moisture, availability of organic matter and $\mathrm{pH}$ of the soil. They occur in diverse habitats specially those which are dark and moist. Organic materials like humus, cattle dung and kitchen wastes are highly attractive sites for some species. Earthworms are generally absent or rare in soil with a very coarse texture in soil and high clay content or soil with pH $<4$ (Gunathilagraj 1996). Earthworms are very sensitive to touch, light and dryness. As worms breathe through their skin, proper ventilation of air in soil medium is necessary. Water logging in the soil can cause them to come to the surface. Worms can tolerate a temperature range between 5 and $29^{\circ} \mathrm{C}$. A temperature of $20-25^{\circ} \mathrm{C}$ and a moisture of $50-60 \%$ is optimum for earthworm function (Hand 1988; Edwards and Bohlen 1996).

\section{Chemical tolerance in earthworms}

Earthworms in general are highly resistant to many chemical contaminants, organic and inorganic pollutants in soil and usually bio-accumulate them in their tissues without being affected. After the Seveso chemical plant explosion in 1976 in Italy, when a large area inhabited by humans was contaminated with certain chemicals including the extremely toxic TCDD (2,3,7,8-tetrachlorodibenzo- $p$-dioxin), several fauna perished but the earthworms were able to survive. Most versatile was the tiger worms (E. fetida). Earthworms species which ingested TCDD contaminated soils were shown to accumulate dioxin in their tissues and concentrate it on average 14.5-fold (Satchell 1983).
5.1 Bioaccumulation of metals by earthworms

Earthworms can bio-accumulate high concentrations of metals including heavy metals in their tissues without affecting their physiology (Ireland 1983). And this is particularly when the metals are mostly non-bioavailable for plant roots (cannot be absorbed by cell membranes). Earthworms ingest metals with soil, change their ionic state in their gut through physiological action and render them in bio-available form for plants when excreted out. Studies indicate that earthworms can take up and bio-accumulate heavy metals like cadmium $(\mathrm{Cd})$, mercury $(\mathrm{Hg})$, lead $(\mathrm{Pb})$ copper $(\mathrm{Cu})$, manganese $(\mathrm{Mn})$, calcium $(\mathrm{Ca})$, iron $(\mathrm{Fe})$ and zinc $(\mathrm{Zn})$. They can particularly ingest and accumulate extremely high amounts of zinc $(\mathrm{Zn})$ and cadmium $(\mathrm{Cd})$ (Hartenstein et al. 1980). Cadmium is very mobile and may be readily incorporated into soft and non-calcareous tissues of earthworms. Cadmium levels up to $100 \mathrm{mg}$ per $\mathrm{kg}$ dry weight have been found in tissues. Of all the metals $\mathrm{Cd}$ and $\mathrm{Pb}$ appear to accumulate in most species of earthworms at greater level. After removal of the gut contents, the tissues in L. terrestris contained 90-180 mg lead/g dry weight. In L. rubellus and D. rubida it was $2600 \mathrm{mg} / \mathrm{g}$ and $7600 \mathrm{mg} / \mathrm{g}$ dry weight. $\mathrm{Zn}, \mathrm{Mn}$ and Fe were shown to be excreted through the calciferous glands (Ireland 1983). ContrerasRamos et al. (2006) also confirmed that the earthworms reduced the concentrations of chromium $(\mathrm{Cr})$, copper $(\mathrm{Cu})$, zinc $(\mathrm{Zn})$ and lead $(\mathrm{Pb})$ in the vermicomposted sludge (biosolids) below the limits set by the USEPA in 60 days. Earthworms collected from the roadsides and mining sites show higher amounts of heavy metals than those from the other sites and hence can be a 'bioindicator' of heavy metal contamination in soil.

Malley et al. (2006) measured bioaccumulation of copper $(\mathrm{Cu})$ and zinc $(\mathrm{Zn})$ in E. fetida after 10 weeks of experiment (Table 1).

Table 1 indicates that the zinc $(\mathrm{Zn})$ levels are similar regardless of the exposure concentrations which suggest that internal concentrations of $\mathrm{Zn}$ is tissues are regulated by earthworms.

Table 1 Concentration of $\mathrm{Cu}$ and $\mathrm{Zn}$ in E. fetida tissues initially and after 10 weeks

\begin{tabular}{lcl}
\hline & $\mathrm{Cu}(\mathrm{mg} / \mathrm{kg}) \pm \mathrm{SD}$ & $\mathrm{Zn}(\mathrm{mg} / \mathrm{kg}) \pm \mathrm{SD}$ \\
\hline Initial sample & $17.29 \pm 2$ & $108.22 \pm 4$ \\
Control & $20.34 \pm 4$ & $127.54 \pm 8$ \\
Dosage 1 & $104.58 \pm 47$ & $137.52 \pm 8$ \\
Dosage 2 & $158.95 \pm 10$ & $132.03 \pm 16$ \\
Dosage 3 & $213.07 \pm 22$ & $138.51 \pm 18$ \\
\hline
\end{tabular}

Source: Malley et al. (2006) 
5.2 Bio-accumulation of endocrine disrupting chemicals

Recent studies by Markman et al. (2007) have shown that the earthworms can bio-accumulate significantly high concentrations of endocrine disrupting chemical (EDCs) (dibutylphthalate, dioctylphthalate, bisphenol-A and 17 $\beta$-estradiol) in their tissues. Tiger worms (E. fetida) living in sewage percolating filter beds exhibited relatively high concentrations of EDCs; those in garden soil were similarly affected. This occupies great significance as the EDCs in environment (soil and water) pose serious risk to human health and their removal using earthworms (vermiremediation) might be possible.

\subsection{Bio-accumulation of pesticides by earthworms}

A study found that after only one application of the relatively persistent pesticide, aldrin, to soil, more than $34 \%$ was found to be present in the soil 5 years later. Most of the remaining $66 \%$ must therefore have remained in soil, either as unchanged aldrin or in the form of other closely related chemicals formed by the decomposition of aldrin. Several studies have found definite relationship between 'organochlorine pesticide' residues in the soil and their amount in earthworms, with an average concentration factor (in earthworm tissues) of about 9 for all compounds and doses tested (Davis 1971). Several studies have found that earthworms can also either accumulate or degrade 'organochlorine pesticide' and 'polycyclic aromatic hydrocarbons' (PAHs) residues in the medium in which it feeds (Ireland 1983).

\section{Vermiremediation: uptake of chemicals from soil by earthworms and immobilization}

Earthworms uptake chemicals from soil pore water through passive 'absorption' of the dissolved fraction through their integument. Intestinal uptake can also occur as soil is ingested and passed through the gastro-intestinal tract. Earthworms consume relatively large quantities of soil, soil-dwelling microbes and organic matter during their lifetime. Earthworms apparently possess a number of mechanisms for uptake, immobilization and excretion of heavy metals and other chemicals. They either 'bio-transform' or 'biodegrade' the chemical contaminants rendering them harmless in their bodies. Most biotransformations and biodegradation are done in the gut before the contaminants enter the worm tissues. Not all contaminants enter the worm via the GIT. Some simply pass through the gut and are excreted in the casts. Those that enter the gut can be metabolized, complexed and excreted, or sequestered in tissues or vacuoles. While most contaminants are rendered harmless, some might be activated to other toxic forms. This needs further investigation.

\subsection{Biotransformation of contaminants in soil}

Some metals are taken up by earthworms and bound by a protein called 'metallothioneins' which have the capacity to bind metals. Ireland (1979) found that cadmium (Cd) and lead $(\mathrm{Pb})$ are particularly concentrated in chloragogen cells in L. terrestris and D. rubidus, where it is bound in the form of $\mathrm{Cd}$-metallothioneins and $\mathrm{Pb}$-metallothioneins, respectively. Small amounts can be deposited in waste nodules (vacuoles). The chloragogen cells in earthworms appear to accumulate heavy metals absorbed by the gut and immobilize the metals in small spheroidal chloragosomes and vesicles found in these cells.

\subsection{Biodegradation of chemical contaminants in soil}

Ma et al. (1995) found that presence of earthworms in soil enhances the degradation of organic contaminants like phthalate, phenanthrene and fluoranthene. Contaminants are degraded by enzymatic activity called 'Cytochrome $\mathrm{P}$ 450' system working in earthworms. This enzymatic activity has been found to operate particularly in Elsenia fetida which survive the benzo(a)pyrene concentration of $1008 \mathrm{mg} / \mathrm{kg}$ of soil (Achazi et al. 1998). It may be noted that several soil microorganisms, especially bacteria and fungi, also biodegrade several categories of chemicals including hydrocarbons in soil. However, when earthworms are added to the soil they further stimulate and accelerate microbial activity by increasing the population of soil microorganisms and also through improving aeration (by burrowing actions) in the soil; ultimately they enhance the rate of biodegradation. The earthworms excrete the decomposer (biodegrading microbes) microbes from their gut into soil along with nutrients nitrogen (N) and phosphorus (P). These nutrients are used by the soil microbes for numerical growth and their increased numbers in soil promote the degradation of organic contaminants.

Stimulation of microbial activity by earthworms for biodegradation of chemical contaminants in soil has been reported by Binet et al. (1998). Edward and Fletcher (1988) showed that the number of bacteria and 'actinomycetes' contained in the ingested material by earthworms increased up to 1000-fold while passing through the gut. A population of worms numbering about 15,000 can in turn foster a microbial population in billions given the optimal conditions (Morgan and Burrows 1982). 


\section{Vermiremediation of PAH-contaminated soil}

Polycyclic aromatic hydrocarbons (PAHs) refer to a group of over 100 chemicals of which anthracene, benzo(a)pyrene, naphthalene, pyrene are common. They are formed by the incomplete combustion of coal, oil and wood. They are emitted from petroleum refineries and coal-, oil-, and cokefired power plants. PAHs are also produced during production of asphalt, aluminum, machinery and pulp and paper. Some PAHs readily volatalize. People may be exposed to PAHs in the soil where coal, wood or petrol has been burnt. Food grown on such soils may contain PAH. However, several PAHs photodegrade in air over a period of days to weeks. Soil microbes can also degrade PAHs in weeks to months.

US EPA has identified 16 PAHs as 'priority pollutants'. PAHs comprising two or more fused benzene rings have the potential for 'bio-magnification'. PAHs that biomagnify are considered hazardous to living organisms. PAHs are able to 'bio-accumulate' in plants and animals including human beings. Benzo(a)pyrene, benzo(a)anthracene and chrysene are carcinogenic to mammals, mutagenic in animal and bacterial cells, and also teratogenic. Some PAHs can also induce 'immunodepressive effects'. These chemicals are thermodynamically stable, have very low aqueous solubility, are highly hydrophobic, and tend to be strongly associated with particles surface in the environment. Most of them are resistant to volatilization and photolysis and are therefore very 'persistent' under natural conditions with 'half-lives' in soils ranging from 26 days for 'phenanthrene' (a volatile and degradable compound) to 6,250 days for 'benzo(a)anthracene' (a recalcitrant compound) (Sims and Overcash 1983).

Earthworms have been found to accelerate the process of PAH biodegradation by stimulating microbial growth and activity in soil while also removing them by passive absorption and bioaccumulation (Eijsackers et al. 2001; Tang et al. 2002). Earthworms were found to bio-accumulate PAHs in the fatty deposits of their bodies (Contreras-Ramos et al. 2006). Parish et al. (2006) studied the bio-accumulation of PAHs in earthworms from contaminated soils obtained from disused manufacturing gas plant and found that earthworms readily accumulated 3-4 ring PAH compounds but not above that.

Hydrophobic organic contaminants are taken up by the earthworms in two ways:

1. Dermal absorption-passive diffusion from the soil solution through the worms outer membrane;

2. Intestinal absorption - of the compounds from the soil while it passes through the gut (by digestion)

The process of passive diffusion is driven by the concentration gradient between the soil pore water and the earthworm's tissues (Jager et al. 2003). The accumulation increases when the concentration of PAHs in their surrounding soil water or in their food increases (Belfroid et al. 1995). Johnsen et al. (2005) also reported that the earthworms may absorb PAHs dermally and via the gut selectively feeding on organic matter to which the PAHs are adsorbed.

Degradation of PAHs occurs when microorganisms break the aromatic rings and produce aliphatic compounds that readily enter the tricarboxylic acid cycle (metabolic activity) operating in living cells. Cunniughamela elegans and Candida tropicalis have been reported to degrade PAHs (Kanaly and Harayama 2000). Singleton et al. (2003) studied the bacterial flora associated with the intestine and vermicasts of the earthworms and found species like Pseudomonas, Paenibacillus, Azoarcus, Burkholderia, Spiroplasm, Acaligenes and Acidobacterium. Some of them, such as Pseudomonas, Acaligenes and Acidobacterium, are known to degrade hydrocarbons. Some fungi such as Pencillium, Mucor and Aspergillus have also been found in the intestine of earthworms and they degrade hydrocarbons. Acaligenes can even degrade PCBs and Mucor dieldrin (Johnsen et al. 2005).

\subsection{Preliminary vermiremediation study}

Contreras-Ramos et al. (2006) studied the uptake of three PAHs (phenanthrene, anthracene and benzo(a)pyrene) at different concentrations by E. fetida and measured the concentrations of PAHs in the soil and in the tissues of earthworms exposed to the PAHs for 11 weeks. Earthworms (10 individuals) were added to $50 \mathrm{~g}$ of soil (equal to 200 worms per kilogram of soil) and moisture was maintained at a level of $70 \%$. The concentration of anthracene decreased by two-fold after addition of earthworms and the average removal from soil was $51 \%$. Only $23 \%$ of PAHs dissipated when earthworms were not added to the soil. On average, the concentration of benzo(a)pyrene decreased by 1.4 -fold and the average removal was $47 \%$ and $13 \%$ when earthworms were present or absent, respectively. Phenanthrene was completely removed $(100 \%)$ by earthworms when the amount of the chemical was $<100 \mathrm{mg} / \mathrm{kg}$ of soil, while dissipation was only $77 \%$ in the absence of earthworms (Table 2). No earthworms survived when the chemical was added at the rate of $150 \mathrm{mg} / \mathrm{kg}$ soil.

Results indicate that earthworms do play significant role, both, directly (through ingestion and enzymatic degradation) and indirectly (by stimulating microbial action) in removal of PAHs from soil. Ma et al. (1995) also found that the removal of phenanthrene and fluoranthene (also a PAH) in soil was accelerated by earthworms. After 56 days ( 8 weeks), $86 \%$ of the phenanthrene was removed. 
7.2 Experimental study of vermiremediation of PAH contaminated soil

Soil contaminated with PAHs was obtained from a former gas works site in Brisbane where gas was being produced from coal. Total PAHs in site soil was greater than $11,820 \mathrm{mg} / \mathrm{kg}$ of soil (Ryan 2006). The legislative standards for soil PAHs is only $100 \mathrm{mg} / \mathrm{kg}$ for industrial sites and $20 \mathrm{mg} / \mathrm{kg}$ for residential sites.

Contaminated soil (10 kg) was collected and placed into each of four 40-L black HDPE containers to represent four different treatments. The first treatment served as a control and no manipulation was done. The second and third treatment had approximately 500 earthworms in about $2 \mathrm{~kg}$ of bedding materials added to the soil. The bedding material work as a primary feed material for the worms. The earthworms were a mixture of three species (E. fetida, E. euginae and $P$. excavatus $)$ and varied in age and size. Semi-dried cow dung ( $\sim 5 \mathrm{~kg}$ ) was added to the contaminated soil in the second treatment and $\sim 5 \mathrm{~kg}$ of kitchen waste was added to the contaminated soil in the third treatment. The fourth treatment had no worms but $5 \mathrm{~kg}$ of organic compost was added. Organic compost is known to contain enormous amount of decomposer microbes. The latter treatment was established to assess the effect of microbial activity on the contaminated soil in the absence of earthworms. Moisture content of the four treatments was maintained between 70 and $80 \%$. The test containers were incubated for 12 weeks at room temperature in the glass house. They were kept under shade thoroughly covered with thick and moist newspapers to prevent any volatilization or photolysis of the PAH compounds in the soil.

Thus, containers 2 and 3 had total of $17 \mathrm{~kg}$ materials (10 kg contaminated soil $+2 \mathrm{~kg}$ of bedding materials with worms $+5 \mathrm{~kg}$ of additional feed material). Container 4 had $15 \mathrm{~kg}$ (10 kg soil $+5 \mathrm{~kg}$ compost). Due to addition of secondary feed materials (cow dung and kitchen waste) and compost in the contaminated soil, significant dilution of PAH compounds was expected and was taken into consideration while determining the impact of earthworms and the microbes in the removal of PAH compounds.

\subsection{Extraction and quantification of PAH compounds}

The extraction of PAHs from soil samples was carried out by the Soxhlet extraction method. Five grams of soil was sub-sampled from each of three treatments-the first (e.g., control) treatment, the second treatment (e.g., earthworms with cow dung), and the third treatment (e.g., earthworms with kitchen waste) and added to $5 \mathrm{~g}$ of anhydrous sodium sulphate and taken in a glass extraction thimble. This was placed into an extraction chamber which then underwent $3 \mathrm{~h}$ of extraction using acetonitrile. After extraction, the samples were cleaned up (purified) to remove any unwanted contaminants.

The gas chromatography-mass spectrometer (GS-MS) and high-performance liquid chromatograph (HPLC) UV or fluorescent light detection were the two main types of instruments used to quantify the extracted PAHs (Ryan 2006). The chromatograph was calibrated by running $100 \mathrm{ppb}$ standard solution (for $35 \mathrm{~min}$ ) through the machine which contained known PAH compounds like benzo(a)pyrene, benzo(a)anthracene, chrysene, benzo(b)flouranthene, benzo(k) flouranthene, anthracene, pyrene, phenthracene, flouranthene, dibenzo(1,2,3,c,d)pyrene and benzo(g,h,i)pyrene. Different PAHs had different retention times with the heavy molecular weight PAHs taking longer time to pass through the Hypersil column. The different retention times were used to determine the type of PAHs compound in the soil solution after comparing with known standard ones. Only seven PAHs compounds indicated in Table 3 were quantified. Dibenzo(a,h)pyrene and benzo(g,h,i)pyrene had identical retention time and hence the values have been entered together (Ryan 2006).

The results of this experiment are summarized by the following observations:

1. There were no noticeable change in the contaminated soil in the control treatment over the 12-week period; however, there was a noticeable hydrocarbon odor throughout the experiment.

2. Earthworms were very active in treatment 2 (added with cow dung) and the hydrocarbon odor disappeared after 2-3 weeks. The soil color slowly changed to brown from black and became more porous and lighter due to formation of worm vermicasts.

3. The soil in treatment 3 (i.e., the contaminated soil, worms and kitchen waste) was invaded by moulds and maggots which disappeared after few weeks. Worms were active and the hydrocarbon odor disappeared after 4-5 weeks. The soil color slowly changed to brown from black and became more porous and lighter due to formation of worm vermicast.

4. The color of soil in treatment 4 changed little and the hydrocarbon odor disappeared slowly over the duration of the test.

The results of the experiment are summarized in Tables 3 and 4 . Table 3 is graphically represented by Fig. 1. Table 4 is graphically represented in Figs. 2 and 3 taking into consideration the dilution factor due to mixing of feed materials with the contaminated soil.

Results confirm that earthworms enhance removal of PAHs from soil by any of the several mechanisms described above i.e. bioaccumulation, enzymatic degradation or microbial degradation. Microbial activity in soil amended with rich organic compost only contributed minimally to the removal of PAHs. This suggests that microbes alone are 
Table 2 Removal of Soil PAHs by earthworms (E. fetida) and by microbial degradation

\begin{tabular}{llll}
\hline PAH & Soil with earthworms & & \multicolumn{2}{c}{$\begin{array}{l}\text { Soil without earthworms (microbial action) } \\
\text { \% Removal }\end{array}$} \\
\cline { 2 - 3 } & Amount decrease & \% Removal & 23 \\
\hline 1. Anthracene & 2-fold & 51 & 13 \\
2. Benzo(a)pyrene & 1.4 -fold & 47 & 77 \\
3. Phenanthrene & Complete & 100 & \\
\hline
\end{tabular}

Note: Contamination $<100 \mathrm{mg} / \mathrm{kg}$ of soil with 10 worms $/ 50 \mathrm{~g}$ of soil for 11 weeks

Source: Contreras-Ramos et al. (2006)

Table 3 Removal of some PAH compounds from contaminated soil by earthworms provided with different feed materials

\begin{tabular}{|c|c|c|c|c|}
\hline Extracted PAH compounds & $\begin{array}{l}\text { Treatment } 1 \text { : Only soil } \\
\text { (control) initial } \\
\text { value }(\mathrm{mg} / \mathrm{kg})\end{array}$ & $\begin{array}{l}\text { Treatment 2: Soil }+ \\
\text { Worms + Cow } \\
\text { dung after } 12 \text { weeks } \\
(\mathrm{mg} / \mathrm{kg})\end{array}$ & $\begin{array}{l}\text { Treatment } 3 \text { : Soil }+ \\
\text { Worms + Kitchen } \\
\text { waste after } 12 \text { weeks } \\
(\mathrm{mg} / \mathrm{kg})\end{array}$ & $\begin{array}{l}\text { Treatment } 4: \\
\text { Soil + Compost } \\
\text { (no worms) after } \\
12 \text { weeks }(\mathrm{mg} / \mathrm{kg} \text { ) }\end{array}$ \\
\hline Benzo(a)anthracene & 3,945 & 929 & 1128 & 2476 \\
\hline Chrysene & 2,694 & 897 & 456 & 1589 \\
\hline Benzo(b)flouranthene & 3,067 & 318 & 101 & 1087 \\
\hline Benzo(k)flouranthene & 315 & 31 & 64 & 189 \\
\hline Benzo(a)pyrene & 726 & 83 & 162 & 367 \\
\hline Dibenzo(a,h)pyrene and Benzo(g,h,i)pyrene & 1,072 & 179 & 492 & 497 \\
\hline Total measure & 11,819 & 2437 & 2403 & 6205 \\
\hline
\end{tabular}

Note: $10 \mathrm{~kg}$ contaminated soil +500 worms $*$ in $2 \mathrm{~kg}$ bedding materials to which was added additional feed materials-cow dung (5 $\mathrm{kg})$ in Treatment 2 and kitchen waste $(5 \mathrm{~kg})$ in Treatment 3 . Compost $(5 \mathrm{~kg})$ was added in Treatment 4

Mixed species of worms (E. fetida, P. excavatus and E. eugeniae) were used

Table 4 Percent removal of some PAH compounds from contaminated soil by earthworms provided with different feed materials

\begin{tabular}{lllr}
\hline Extracted PAH compounds & $\begin{array}{l}\text { Treatment 2: Soil + } \\
\text { Worms + Cow dung } \\
\text { after 12 weeks }\end{array}$ & $\begin{array}{l}\text { Treatment 3: Soil + } \\
\text { Worms + Kitchen } \\
\text { waste after 12 weeks }\end{array}$ & $\begin{array}{l}\text { Treatment 4: Soil + } \\
\text { Compost (no worms) } \\
\text { after 12 weeks }\end{array}$ \\
\hline Benzo(a)anthracene & $76 \%(58 \%)$ & $71 \%(56 \%)$ & $37 \%(6 \%)$ \\
Chrysene & $67 \%(49 \%)$ & $83 \%(68 \%)$ & $41 \%(12 \%)$ \\
Benzo(b)flouranthene & $90 \%(72 \%)$ & $97 \%(82 \%)$ & $65 \%(47 \%)$ \\
Benzo(k)flouranthene & $90 \%(72 \%)$ & $80 \%(65 \%)$ & $40 \%(10 \%)$ \\
Benzo(a)pyrene & $89 \%(71 \%)$ & $78 \%(63 \%)$ & $49 \%(24 \%)$ \\
Dibenzo(a,h)pyrene and Benzo(g,h,i)pyrene & $83 \%(65 \%)$ & $54 \%(39 \%)$ & $54 \%(30 \%)$ \\
Average & $79 \%(61 \%)$ & $80 \%(65 \%)$ & $47.5 \%(21 \%)$ \\
\hline
\end{tabular}

Note: $10 \mathrm{~kg}$ contaminated soil +500 worms $*$ in $2 \mathrm{~kg}$ bedding materials to which was added additional feed materials- $\mathrm{cow}$ dung $(5 \mathrm{~kg})$ in Treatment 2 and kitchen waste $(5 \mathrm{~kg})$ in Treatment 3 . Compost $(5 \mathrm{~kg})$ was added in Treatment 4

(\%) Values within parenthesis are those after taking the dilution factor (due to mixing of additional feed materials) into account

less effective for removal of PAHs than when worms are present. This is likely because earthworm guts contain microfauna and microflora with the capacity to degrade hydrocarbons. Singleton et al. (2003) has reported some 'uncultured' bacterial flora tightly associated with the intestine of the earthworms. Some of them, such as Pseudomonas, Acaligenes and Acidobacterium, are known degrader of hydrocarbons.
Providing earthworms with additional feed materials (in the form of cow dung or kitchen waste-both organics) must have played important role in accelerating worm activity and in its reproductive behavior, and also in stimulating the soil microbial activity. There was not much significant difference in the impact of two types of feeds. Ma et al. (1995), however, showed an increase in loss of PAHs from polluted soil when the worms were denied of 
Fig. 1 Removal of some PAHs compounds (in $\mathrm{mg} / \mathrm{kg}$ ) from contaminated soil by earthworms, provided with different feed material

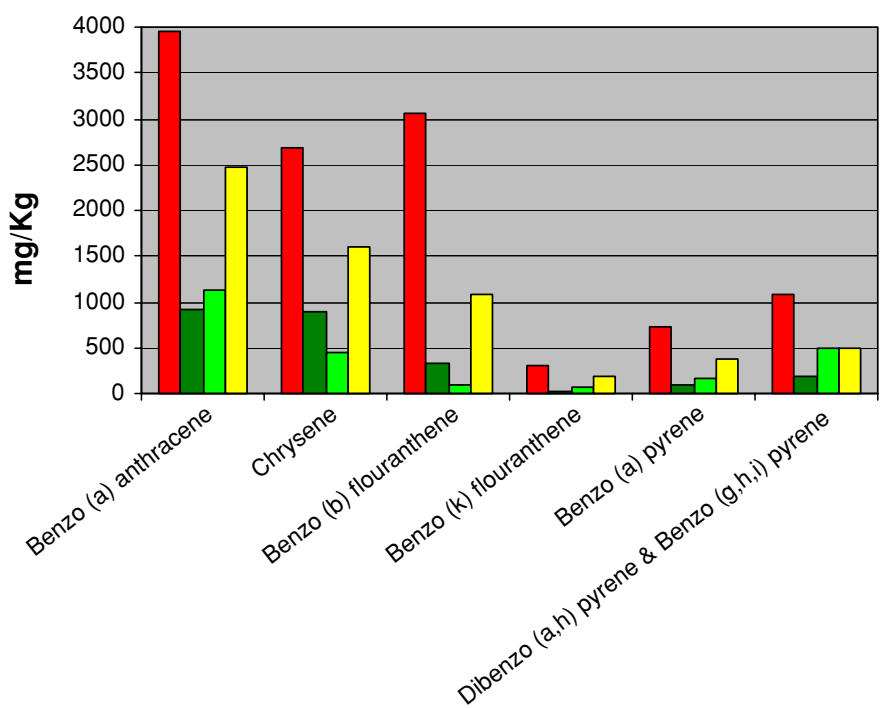

Treatment -1 (Only Soil) Initial Value

- Treatment- 2 (Soil+worms+Cow dung)After 12 weeks

$\square$ Treatment- 3 (Soil+worms+Kitchen waste) After 12 weeks

$\square$ Treatment - 4 (Soil + Compost) After 12 weeks
Fig. 2 Percent removal of PAHs from contaminated soil by earthworms, provided with different feed materials

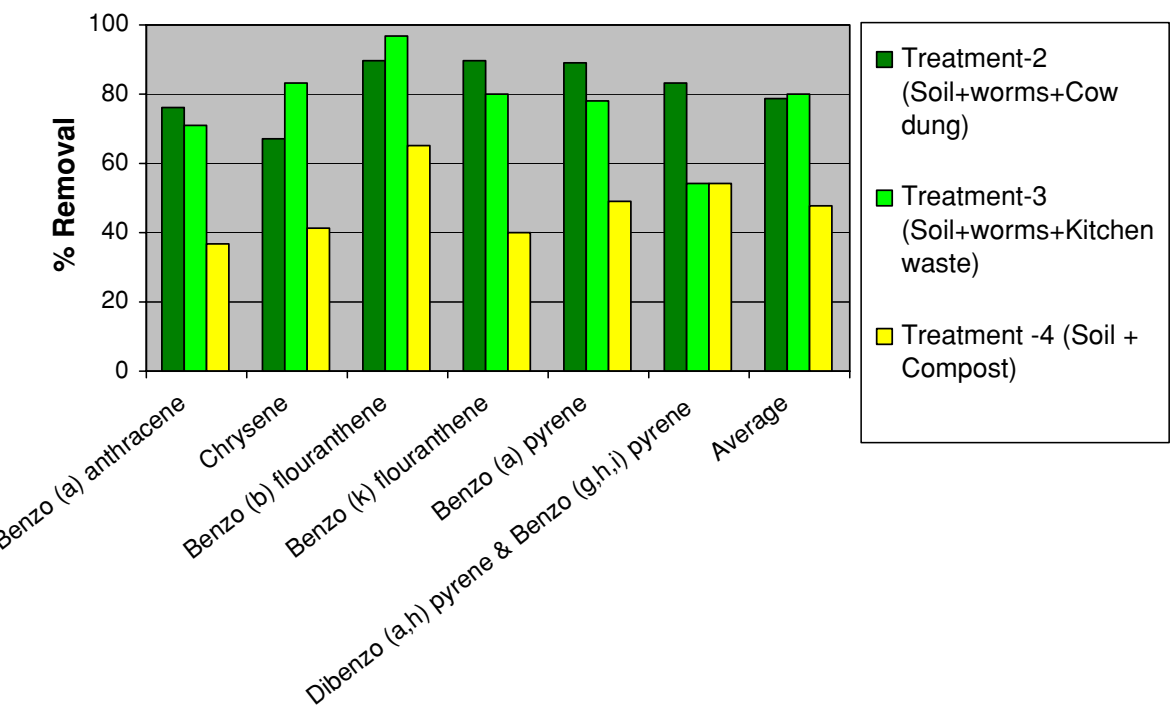

Extracted PAH Compounds any additional source of food. They concluded that earthworms increase oral intake of soil particles when driven by 'hunger stress' and consequently ingested more PAHs polluted soil.

\section{Economic and environmental sustainability of vermiremediation technology}

Vermiremediation technology by earthworms is a selfpromoted, self-regulated, self-improved, self-driven, selfpowered and self-enhanced, low or no energy requiring zero-waste technology, easy to construct, operate and maintain. Any vermiculture technology involves about 100-1000 times higher 'value addition' than other biological technologies (Hand 1988). Obtaining earthworms from vermiculture farms would be one-time cost in any vermiremediation technology as the earthworms multiply rapidly creating huge army of worms which further promote and enhance the process (Sinha and Sinha 2007).

Vermiremediation of chemically polluted/contaminated soils/lands would cost about \$500-1000 per hectare as compared to $\$ 10,000-15,000$ per hectare by mechanical excavation of contaminated soil and its landfill disposal. Of considerable economic and environmental significance is that the worm feed used in vermiremediation process is necessarily an 'organic waste' product. This means that it would also lead to reuse and recycling of vast amount of organic wastes which otherwise end up in landfills for disposal at high cost. And what is of still greater economic and environmental significance is that the polluted land is not only 'cleaned-up' but also 'improved in quality'. 
Fig. 3 Percent removal of some PAHs compounds from contaminated soil by earthworms provided with different feed materials, after taking the dilution factor (due to mixing of feed materials) into account

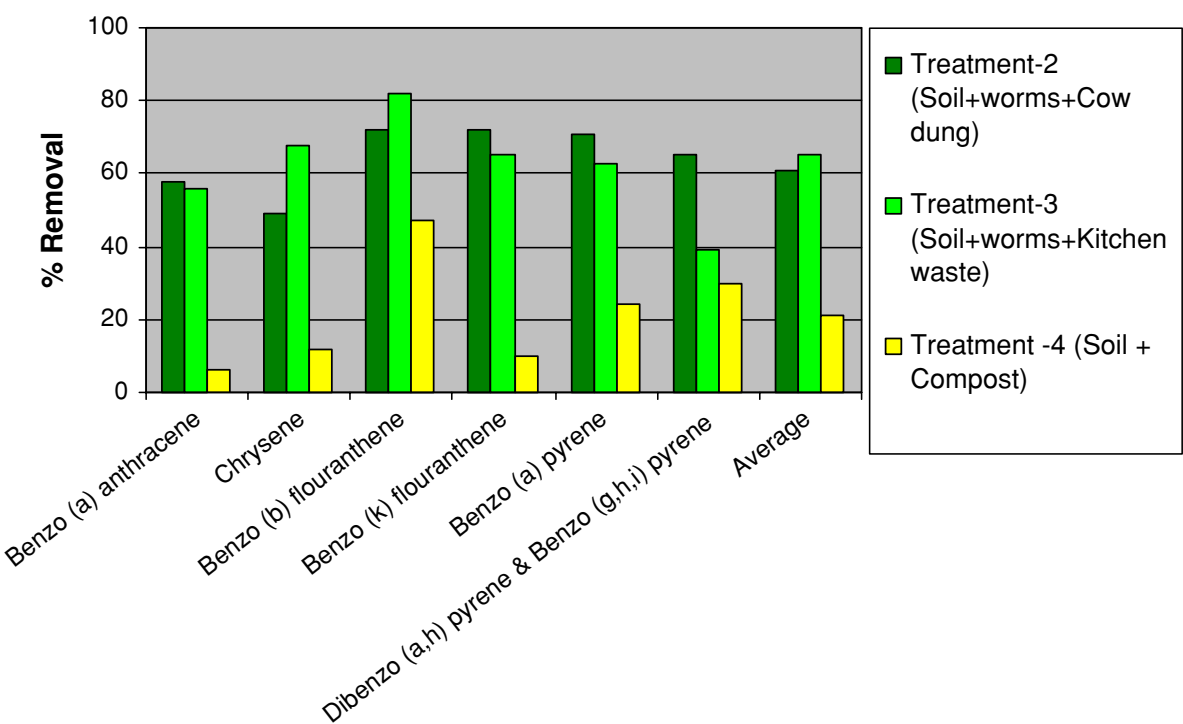

Extracted PAH Compounds

Earthworms improves the fertility of soil by adding its excreta-the vermicast (as vermicompost) which contains rich nutrients (NKP and micronutrients), enzymes and growth hormones and beneficial nitrogen-fixing and decomposer microbes. The soil becomes lighter and porous rich in biological activities and the productivity is increased to several times. Earthworms not only convert the 'wasteland' into 'wonderland' it itself becomes a valuable asset. Vermiculture is a flourishing industry. The cost of approximately 1000 worms in Australian market is about \$32.

\section{Conclusions and recommendations}

Earthworms can remove hydrocarbons and many other chemicals from contaminated soil, even benzo(a)pyrene, which is a PAH very resistant to degradation (ContrerasRamos et al. 2006). They are extremely resistant to toxic PAHs and tolerate concentrations normally not encountered in the soil. Our results shows that nearly $80 \%$ (60-65\% if the dilution factor is taken into account) of seven important PAHs were removed in just 12 weeks with a loading rate of about 50 worms per $\mathrm{kg}$ of soil. This occurred during the winter season in Brisbane (March-May 2006) when the biological activities of worms are lowest. Increasing the loading rate to 100 worms per $\mathrm{kg}$ of soil and extending the remediation to 16 weeks might have resulted in a complete removal of the PAHs. Contreras-Ramos et al. (2006) got a 50-100\% reduction of PAHs in 11 weeks with a loading rate of 200 worms $/ \mathrm{kg}$ soil.

Many soils contain abundance of pores with diameters of $20 \mathrm{~nm}$ or less. Such pores are too small to allow the smallest bacterium $(1 \mu \mathrm{m})$, protozoa $(10 \mu \mathrm{m})$ or root hairs $(7 \mu \mathrm{m})$ to penetrate and attack the chemicals. A chemical contaminant residing in such fine soil pores is completely protected from attack by a microbe in the soil for biodegradation action. In other words, such chemical contaminants are not 'bio-available'. Earthworms play an important and critical role here by enlarging the pores through continuous 'burrowing actions' in the soil, thus allowing the microbes to enter into the pores and act on the contaminants. They also enhance the population of microbial decomposers to enhance degradation. The 'gizzard' in the earthworms helps to grind the food very thoroughly with the help of tiny stones swallowed by the worms into smaller particles $2-4 \mu \mathrm{m}$ in size. This grinding action may serve to make PAHs or any other chemical contaminants sequestered in the soil 'bio-available' to decomposer microbes for degradation.

Vermiremediation may prove a very cost-effective and environmentally sustainable way to treat polluted soils and sites contaminated with hydrocarbons in just few weeks to months. With the passage of time, the remedial action is greatly intensified. As worms reproduce relatively rapidly, they can quickly achieve levels of enhanced degradation of PAHs. In comparison to the cost of mechanical treatment by excavation of contaminated soils, this technology is economical.

Significantly, vermiremediation leads to significant improvement in the quality of soil and land where they inhabit. During the vermiremediation process of soil, the population of earthworms increases significantly benefiting the soil in several ways. A 'wasteland' is truly transformed into 'wonderland'.

Acknowledgements The authors are grateful to Prof. Bofo Yu (HOS of Environmental Engineering and former Director of CESR at 
Griffith University), Prof. Roger Braddock and Roger Cropp (past and present Directors of CESR), for providing the financial support to carry out the research program. We also thank Jane Giffkins and Michelle in the PC 2 lab for providing the laboratory support and Ehrsam Werner for providing space in the PC 2 lab. Gokul Bharambe deserves special credit for drawing the graphs.

\section{References}

Achazi RK, Fleener C, Livingstone DR, Peters LD, Schaub K, Schiwe E (1998) Cytochrome $P 450$ and dependent activity in unexposed and PAH-exposed terrestrial annelids. J Comp Biochem Physiol C 121:339-350

Belfroid A, Meiling J, Drenth HJ, Hermens J, Seinen W, Gestel KV (1995) Dietary uptake of superlipophilic compounds by earthworms (Eisenia andrei). Ecotoxicol Environ Saf 31:185-191

Bhawalkar V, Bhawalkar U (1994) Vermiculture biotechnology. Bhawalkar Earthworm Research Institute (BERI), Pune, India

Binet F, Fayolle L, Pussard M (1998) Significance of earthworms in stimulating soil microbial activity. Biol Fertil Soils 27:79-84

Butt KR (1999) Inoculation of earthworms into reclaimed soils: the UK experience. J Land Degrad Dev 10:565-575

Chaoui HI, Zibilske LM, Ohno T (2003) Effects of earthworms casts and compost on soil microbial activity and plant nutrient availability. Soil Biol Biochem 35(2):295-302

Contreras-Ramos, Silvia M, Alvarez-Bernal, Dioselina \& Dendooven Luc (2006) Eisenia fetida increased removal of polycyclic aromatic hydrocarbons (PAHs) from soil. Environ Pollut 141:396-401; Elsevier Pub

Davis B (1971) Laboratory studies on the uptake of dieldrin and DDT by earthworms. Soil Biol Biochem 3:221-223

Edward CA, Lofty JR (1972) Biology of earthworms. Chapman and Hall, London, p 283

Edwards CA, Bohlen PJ (1996) Biology and ecology of earthworms, 3rd edn. Chapman and Hall, London

Edwards CA, Fletcher KE (1988) Interaction between earthworms and microorganisms in organic matter breakdown. Agric Ecosyst Environ 24:235-247

Eijsackers H, Van Gestel CAM, De Jonge S, Muijis B, Slijkerman D (2001) PAH - polluted peat sediments and earthworms: a mutual inference. J Ecotoxicol 10:35-50

Gerard BM (1960) The biology of certain British earthworms in relation to environmental conditions. Ph.D Thesis, University of London

Gunathilagraj K (1996) Earthworm: an introduction; Indian Council of Agricultural Research Training Program. Tamil Nadu Agriculture University, Coimbatore

Hartenstein R, Neuhauser EF, Collier J (1980) Accumulation of heavy metals in the earthworm E. foetida. J Environ Qual 9:23-26

Hand P (1988) Earthworm biotechnology. In: Greenshields R (ed) Resources and application of biotechnology: the new wave. MacMillan Press Ltd., USA

Ireland MP (1979) Metal accumulation by the earthworms Lumbricus rubellus, Dendrobaena veneta and Eiseniella tetraedra living in heavy metal polluted sites. Environ Pollut 19:201-206

Ireland MP (1983) Heavy metals uptake in earthworms; earthworm ecology. Chapman \& Hall, London

Jager T, Baerselman R, Dukeman E, De Groot AC, Hogendoorn EA, Jong AD, Kruitbosch J, Peijn W (2003) Availability of PAH to earthworms (Elsenia andrei) in field polluted soil and soilsediment mixtures. J Environ Toxicol Chem 22(4):767-775

Johnsen AR, Wick LY, Harms H (2005) Principles of microbial PAH degradation in soil. J Environ Pollut 133:71-84

Kanaly RA, Harayama S (2000) Biodegradation of high molecular weight PAHs by bacteria. J Bacteriol 182:2059-2067

Ma WC, Imerzeel J, Bodt J (1995) Earthworm and food interactions on bioaccumulation and disappearance of PAHs: studies on phenanthrene and flouranthene. Ecotoxicol Environ Saf 32:226-232

Malley C, Nair J, Ho G (2006) Impact of heavy metals on enzymatic activity of substrate and on composting worms Eisenia fetida. J Bioresour Technol 97:1498-1502

Markman S, Guschina IA, Barnsleya S, Buchanan KL, Pascoe D, Muller CT (2007) Endocrine disrupting chemicals accumulate in earthworms exposed to sewage effluents; Cardiff School of Biosciences, Cardiff University, Cardiff, U.K. J Chemosphere 70(1):119-125

Morgan M, Burrows I (1982) Earthworms/Microorganisms interactions; Rothamsted Exp. Stn. Rep.

OECD (2000) Guidelines for testing organic chemicals. Proposal for new guidelines: earthworms reproduction tests (E. fetida andrei); Organization for Economic Co-operation and Development (www.oecd.org)

Parish ZD, White JC, Asleyan M, Gent MPN, Lannucci-Berger W, Eitzer BD, Kelsey JW, Mattina MI (2006) Accumulation of weathered PAHs by plant and earthworms species. J Chemosphere 64(4):609-618

Ryan D (2006) Vermiremediation and other bioremediation options for PAHs contaminated soil; Project report submitted for the partial fulfillment of the degree of Bachelor of Environmental Engineering, School of Engineering, Griffith University, Brisbane (Supervisor: Dr. Rajiv Sinha)

Safawat H, Hanna S, Weaver RW (2002) Earthworms survival in oil contaminated soil. J Plant Soil 240:127-132

Satchell JE (1983) Earthworm microbiology. In: Satchel JE (ed) Earthworm ecology-from Darwin to Vermiculture. Chapman and Hall Ltd., London, pp 351-364

Sims RC, Overcash MR (1983) Fate of polynuclear aromatic hydrocarbons (PNAs) in soil-plant systems. Residue Rev 88:2-68

Singleton DR, Hendrix BF, Coleman DC, Whitemann WB (2003) Identification of uncultured bacteria tightly associated with the intestine of the earthworms Lumricus rubellus. Soil Biol Biochem 35:1547-1555

Sinha RK, Herat S, Agarwal S, Asadi R, Carretero E (2002) Vermiculture technology for environmental management: study of action of earthworms Elsinia foetida, Eudrilus euginae and Perionyx excavatus on biodegradation of some community wastes in India and Australia. The Environmentalist, U.K. 22(2): 261-268.

Sinha RK, Sinha R (2007) Environmental biotechnology (Role of plants, animals and microbes in environmental management and sustainable development). Aavishkar Publisher, Jaipur, India; ISBN 978-81-7910-229-9; p 315

Tang J, Liste H, Alexander M (2002) Chemical assays of availability to earthworms of PAHs in soil. J Chemosphere 48:35-42

Visvanathan C, Traenklar J, Joseph K, Nagendran R (eds) (2005) Vermicomposting as an eco-tool in sustainable solid waste management; Project report of The Asian Regional Research Program on Environmental Technology (ARRPET); Pub. of Asian Institute of Technology (AIT), Anna University, India; $\mathrm{p} 36$ 